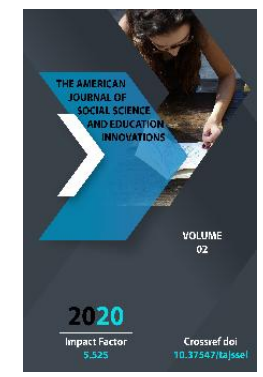

Journal Website: http://usajournalshub.c om/index,php/tajssei

Copyright: Original content from this work may be used under the terms of the creative commons attributes 4.0 licence.

\section{Historical Considerations Of Rural Areas Of The Ancient Kesh Oasis}

\author{
Orifhuja Odilovich Muminov \\ Scientific Staff, National Archeological Center Of The Academy Of Sciences Of The Republic \\ Of Uzbekistan, Uzbekistan
}

\title{
ABSTRACT
}

Kesh (Arabic, in its sources Kashsh, Kass, Kise) is a historical city and region. It occupies the northeastern part of the present-day Kashkadarya region of Uzbekistan. Initially, it was located on the site of Kitab district, then in the 9th-10th centuries it moved to Shakhrisabz. Extensive research has been conducted in the Kesh oasis over the years, which has provided valuable information on the ancient and medieval history of the oasis. Important information about the ancient and medieval history of the oasis is given in the sources. These sources provide detailed information on the geographical location of the Kesh oasis, the lifestyle of the population of the oasis, the socio-economic life of the oasis, the structure of the city of Kesh. Historians such as Ibn Hawqal and Al-Muqaddas have provided such valuable information in their works. From the 2oth century, archeological excavations began in the oasis. Preliminary research was conducted by orientalists in the oasis. In the oasis V.V.Bartold, V.A.Vyatkin, B.Denike conducted scientific research. In 1926, A.Yu.Yakubovsky was sent to Shakhrisabz to study historical topography. In the 1930s, the monuments of Shakhrisabz were studied by Y.G.Gulomov, T.M.Mirgiyosov, S.K.Kabanov, S.A.Sudakov and the artist N.S.Lojkin. Archaeological excavations in the oasis were also carried out by M.E. Masson in the 1940 . Archaeological excavations were carried out by S.K.Kabanov in 1946-1950. In 1955, V.D.Zhukov conducted excavations at the site of Kindiklitepa. The research conducted by N.I.Krasheninnikova in 1970-1980 is also important. Similar expeditions were carried out in later periods. Among them are R.H.Suleymanov, E.V.Rtveladze and A.S.Sagdullaev. The archeological researches and scientific researches of these scientists are served as an important basis in determining the age of the cities of the eastern (Kesh) and western (Karshi) oasis of Kashkadarya and their place in the urban culture of Central Asia. 


\section{KEYWORDS}

Central Asia, Kesh, Karshi, Kitob, Shakhrisabz, Nautaka, Ksenippa, Erkurgon, Uzunkir, Kashkadarya, Kindiklitepa, East, West, Syrdarya, Al-Muqaddas, Sangirtepa, Mirzachul, Margiyana, Sogdiana, Shurobsoy, Osuvdarya, Saroytepa, Qayragochtepa, Kattakontepa, bathhouse, medieval, coin, brick, ceramic.

\section{INTRODUCTION}

The Kashkadarya oasis (South Sogd) is one of the ancient historical and geographical regions of Central Asia. The rich history of the oasis has attracted the attention of many researchers. Kashkadarya region is home to a large number of archeological and architectural monuments, centers of folk crafts. The ancient history of the oasis is also rich in important events. The region is located at the crossroads of ancient trade routes, and the information is widely preserved in written sources. At the beginning of the 20th century, the study of the Kitab-Shahrizabz oasis was begun from an archaeological point of view, especially the study of the architectural monuments of Shahrisabz protected by the Association for the Protection of Ancient and Artistic Monuments in Central Asia. In 1925, V.V.Bartold, V.A.Vyatkin, art historian B.Denike, and German art critic E.Kon-Wiener came to Shahrizabz. A.E.Midji, a student of the Turkestan Institute of Oriental Studies, spoke about the Kitab and Shakhrisabz ancient monuments at a meeting of ethnography and archeology of the Turkestan branch of the Russian Geographical Society in Tashkent. ${ }^{1}$ Nautaka and Xenippe are the ancient cities located in the Kashkadarya region. Nautaka (Navtaka) is one of the Sogdian regions, which translates as "new construction", "new place". In Arrian's work, Nautaka is described

\footnotetext{
${ }^{1}$ Excerpts from the history of ancient KeshShakhrisabz // Editor-in-Chief: A.S.Sagdullaev.T. "Shark" 1998. p. 10-.11
}

as "the husband of the Sogdians." There are various opinions in the scientific literature about the location of Nautaka. In particular, Nautaka is considered to be the name of a large region stretching from the city of Shakhrisabz to the Amudarya. According to written sources, the territory of Kashkadarya is divided into two regions: Nautaka and Ksenippe, which correspond to the territories of Shakhrisabz and Karshi regions. In particular, the areas can be divided into upper valley and lower valley parts. In the upper part is Nautaka that is Kesh (Sakhrisabz), in the lower part is Ksenippe Naqshab (Karshi). ${ }^{2}$ M.E. Masson, by contrast, placed Ksenippe in the upper valley and Nautaka in the lower valley. Erkurgan (near Karshi) is located on the site of the monument Nautaka. ${ }^{3}$ Ksenippe is the name of the Sughd region near to the lands of Nautaka. Researchers, based on written sources, have come to various conclusions by placing the lands of Ksenippe in the Kashkadarya oasis: Shakhrisabz district or Boysun oasis (V.V.Grigorev), Lower Kashkadarya (V.Tomashek), the north-eastern region of Shakhrisabz (I.G.Drozen), Kitob (M.G.Masson) Karshi oasis (A.S.Sagdullaev).

\footnotetext{
${ }^{2}$ Naxsheb na rubeje drevnoste i srednevekovya // S.K.Kabanov // Tashkent 1977 // p88

${ }^{3}$ Stolichnye goroda v oblasti nizovev Kashkadari s drevneyshix vremen.// M.E.Masson // 6-10p
} 


\section{THE MAIN FINDINGS AND RESULTS}

As a result of research It was conducted by A.S.Sagdullayev of the Department of Central Asian Archeology of Tashkent State University in 1976-1979, a number of monuments of the Early Iron Age were discovered in the eastern part of the Kashkadarya oasis. As a result of many years of research at the Daratepa monument, Various settlements of the VII-IV centuries were excavated. ${ }^{4}$

In 1981-1984, an expedition led by N.I.Krasheninnikova discovered the monuments of Sangirtepa, Uzunkir, Podayotoktepa in the first half of the first millennium $B C$ in the middle reaches of the Shorobsoy, as well as conducted research on their defensive walls. Studies here show that the Uzunkir and Podayotoktepa monuments are about 700-800 meters away, and the Sangirtepa monument is located south of the Uzunkir monument and there is about $1 \mathrm{~km}$ between them. The results of the research show that the first period of formation of Sangirtepa was in BC. It dates back to the IXVIII centuries. During this period, a large structure with a strong cotton wall was built here. In the VIII-VI centuries BC, the monuments were developed and constructed. Remains of a human skeletal bone from the IX-VII centuries have also been found. The research was carried out on a central rectangular hill with a height of $8 \mathrm{~m}$ and dimensions of $85 \times 65 \mathrm{~m}$ in Sangirtepa. Sangirtepa is surrounded by defensive walls on the south and west sides and has a total area of 3 hectares. The excavation carried out in the north-western part of the central hill of Sangirtepa shows that the thickness of the cultural layer was 6.85 meters. The strategy

\footnotetext{
${ }^{4}$ Views from the history of ancient Kesh-Shakhrisabz // Responsible editor: A.S.Sag'dullaev.T. "Shark" 1998.

p. 13.
}

shows that life in this part of the central hill is complicated and there are four construction periods. No new information has been obtained as a result of the excavation work carried out on the western and north-western sides of the hill, but as a result they have found habitats in this part of the monuments, and rotten and ash layers for storage of goods from this place, indicates that it was used as a black.

Archaeological and strategic research in Sangirtepa revealed the history of the settlement, its development and stages of abandonment. The first period of formation of Sangirtepa was in BC. It belongs to IX-VIII centuries. During this period, a large structure with a strong cotton wall was erected here. The first is the presence of an outer cotton wall for the earliest period, and it can be assumed this wall, which has been preserved throughout the life of the monument, served a defensive purpose.

There is a need to strengthen the developed part of the settlement, as a result of which the area of about 3 hectares will be surrounded by a wall barrier. Sangirtepa is surrounded by strong and thick walls and becomes the residence of the local ruler. $^{5}$ Archaeological evidence suggests that life in Sangirtepa ceased in the 4th and 1st centuries BC, evidenced by abandonment and depression. Monuments of this type were common in Margiyana, Bactria, and Sogdiana during the Early Iron Age, and in many cases they occupied small areas, but they were surrounded by defensive walls, a sign of military strategic importance. Similar symbols are found in Sangirtepa, which can be included in the category of monuments, which are the strongholds of the big city. According

\footnotetext{
${ }^{5}$ Eshov B.J.History and Culture of Sogdiana VII-IV vv T., 1999, p10.
} 
to A.Sagdullayev and N.I.Krasheninnikova, Uzunkir and the region in general were called "Nautaka" in their time.

The ancient Sogdian word translates as "Nautaka". The suffix "Tak" is interpreted to mean "power", "might", "strength", and this concept is derived from the process of building a large fortified military base in the place of Uzungir,surrounded by strong and thick defensive walls. It can be assumed to have originated. Archaeological excavations were also carried out in Podayotoktepa and Uzunkir, and their defensive walls were studied. As a result of research, an ancient agricultural oasis was formed on the banks of the Shurobsoy in the early 1st millennium BC. In the early Iron Age, Sogdiana was a separate territorial order group with several types of settlements that served as centers.

In 1983, N.I.Krasheninnikova conducted research on the surviving part of the Uzunkir defensive wall. During the research, the remains of a room with an entrance and a single window were examined from the outside of the wall. The walls and level of the room are plastered with straw.

Fragments of pottery and three arches of bronze arrows were found on the surface. ${ }^{6}$ Research suggests that the castle wall was built during the Achaemenid period. According to the result of research by A.S.Sagdullayev and N.I.Krashennikovs the Uzunkir was considered the center of the city of Nautaka, and later the center will be replaced by the city of Kitab. ${ }^{7}$ Work on the study of the defensive wall and the territory of the settlement in Uzunkir was resumed in

\footnotetext{
${ }^{6}$ Excerpts from the history of ancient KeshShakhrisabz // Editor-in-Chief: A.S.Sagdullaev.T. "Shark" 1998.p. 46-47.

${ }^{7}$ Eshov.B. History of state and local government in Uzbekistan T.2012 P.67-69.
}

1986 by an archeological expedition led by A.S.Sagdullayev. At the site of the excavations by N.I.Krasheninnikova, a clear image of the exterior of the wall can be seen. Exploration of the southern part of the long defensive wall continued.

The results of research and data from the pits indicate the existence of the first Iron Age city center instead of Uzunkir. The findings of the study of the defensive wall of the Uzunkir settlement provided new information about the defensive architecture of the Early Iron Age of southern Sogd. The area of Uzunkir was 70 hectares. The remnants of the western, eastern and southern defensive walls of Uzunkir were 20 meters thick. It is surrounded by an artificial ditch found in Shurobsoy, and for the northern side such a ditch was performed by Shurobsoy itself. The places of three gates were unknown.

In the following period, Uzunkir was expanded. Its expansion has led to the need to build fortifications to protect the population. In the 7th-6th centuries BC, a complex defense system emerged: a defensive wall protruding from a solid wall made of raw bricks, fortified with towers to the tower rooms and plasters. But in the first period the thickness of the Long Wall was only 1.85 meters between the towers, probably due to the construction of an additional second wall. ${ }^{8}$

Southern Sogdia, separated from the Samarkand Mountains by mountains, dates back to $B C$. In the first half of the first millennium, the findings from the monuments of the region, which was historically close to Northern Bactria, are a clear proof of this. Geographical conditions have led to the

\footnotetext{
${ }^{8}$ Rtveladze.EV, Saidov A.H, Abdullaev E.V, Civilization of ancient Uzbekistan: excerpts from the history of statehood and law. T., 2001. p.4-5.
} 
formation of specific material cultural features in the Sogdian regions, which have been preserved for centuries. Such differences can be traced back to the Early Iron Age, when the first cities were formed in the Southern Hemisphere. Sangirtepa and Uzunkir data show this. The expansion of settled agricultural and livestock oases has led to the intermingling of local peoples, the addition and transformation of advanced traditions, and the formation of a single economic and cultural species, as evidenced by the findings of Sangirtepa. Favorable weather conditions and the availability of fertile land are also major reasons for these processes, reflecting the search for new areas suitable for farming and animal husbandry by the peasant tribes. South Sogdia Research, strategic data and analysis of archeological complexes on the monuments of the beginning and middle of the 1st millennium allow us to distinguish the following peculiarities: the location of the population along the oasis, the construction of single economic and cultural centers, the high level of construction style, the application of various architectural planning methods is associated with the emergence of advanced ceramics and metallurgy.

In antiquity (late 4th century BC to 4th century AD) a number of important changes took place in the socio-economic and cultural life of the population of the Kashkadarya oasis, the southern region of Uzbekistan. The country under study could not stay away from the process of formation and development of ancient centralized states in Uzbekistan. ${ }^{9}$

At the turn of the III-II centuries BC, the capital of eastern Kashkadarya moved from the Shurobsoy oasis to the middle reaches of the

\footnotetext{
${ }^{9}$ Hasanov.M., And Mexendali.S. Raskopki na Sangirtepe v Kashkadary // Arxeologicheskie isseledovaniya v Uzbekistana. 2003 T " Uzb milliy entsiklopediyasi" 2004. p. 183
}

Osuvdarya, in the district of Kitab. Underneath the present-day buildings of the city of Kitab are hidden layers of the III century $B C$ to the VII century AD. In ancient times, cultural ties and interactions (the merging of Greek and local cultures) were also explained by the rapid development of trade and monetary relations. All this leads to the formation of official communication and trade routes between the various regions of Central Asia. Archaeological sources of the ancient period allowed to raise the issue of ancient religious views of the population of the Kashkadarya oasis. Based on the opinion of researchers, A.Omelchenko studies the topological and internal structure of ancient settlements in the eastern part of South Sogd as follows: The central city of the region (Suse-Kitab, area 40 hectares) settlements (Saroytepa-Olvontepa in Shurobsoy, area 8-9 hectares; AyakchisaydaKattajartepa area 6.5 hectares; Toldisay and Guldarasoy Qayragochtepa I and Qayragochtepa II area 10-20 hectares; Kattakontepa area in Karabakh 7-8 hectares) . According to the researcher, the total area of ancient settlements located in the eastern part of southern Sogdia is 130 hectares.

Archaeological excavations are mainly carried out in the lower Kashkadarya. S.E.Kabanov's article and information on the preliminary results of archeological excavations will be published. In general, the network of canals and ditches in northern Kashkadarya in the late Middle Ages is considered one of the most developed in Central Asia. Small fortifications were built to protect the population of the oasis and the main structures of the irrigation system. Podayotoktepa is an example of such a fortress. Its top layer dates back to the beginning of antiquity, so the problem of defense was solved to the maximum extent in the existing conditions due to the 
convenience of the place chosen for its construction.

Archaeological research shows that in the IVIII centuries $B C$, in contrast to fortifications and public buildings in eastern Kashkadarya, residential buildings consisted mainly of semibasements and light shelters. In these complexes, cotton and square-shaped raw bricks, typical of antiquity, were used for low walls and sandals. For example, a group of apartment complexes is located under the interconnected sheds inside the Podayotoktepa wall. ${ }^{10}$

The place of Kitob is considered to be the site of antiquity - the first place is associated with the name of another famous hero of Kalandartepa or Tepai Afrosiyob "Shohnoma". Pre-Islamic sources provide information about this area mentioned in the work of I.Markvant. At present, this information is supplemented to some extent by numismatic materials. In the 70 s and 80 s of the twentieth century, a large-scale map of the eastern part of Kashkadarya addressed the issues of zoning and classification of ancient and medieval monuments and the development of regional culture since the arrival of the first peasant groups. The problem of ancient roads connecting the south and center of Central Asia through the Southern Sogdia and existing since ancient times was highlighted. At the same time, in the III-II centuries BC, more solid houses were built in the Kitab area. In Eastern Kashkadarya, as in Central Asia, where they usually have a special foundation, the use of raw bricks in construction has begun. In ancient times, houses usually consisted of several rooms that served different purposes. In addition to the living rooms with an area of 20-30 square meters, it definitely has a

\footnotetext{
${ }^{10}$ Shakhrisabz is a 2700 thousand year old heritage. Album, Tashkent, Shark 2002, P.76
}

bathroom. In the dining room (8-12 sq. M.) there are a few jars of grain, oil, and wine buried in the ground near the wall, up to half or up to the throat, and sometimes the jars are placed inside the living rooms. ${ }^{11}$

Thus, in the South Sogd there are large areas of development of the Early Iron Age, the development of which will continue in later periods. As early as the IX-VIII centuries, and later in the VII-VI centuries $\mathrm{BC}$, a more clear boundary was formed between the two regions and territories formed in the lower and middle part of Kashkadarya. During the Early Iron Age, the economy, culture, and trade flourished, and the growth of the productive forces led to private ownership and a separate beginning, and raw materials became handicrafts. One of the greatest economic achievements of the Early Iron Age was the spread of ancient agriculture.

\section{CONCLUSION}

After the independence of Uzbekistan, the approach to the study of history has reached a new level. The study of the history of ancient oases, cities in the territory of our country, archeological research was considered as one of the important issues. One of the most important oases in Central Asia, the Kesh oasis has a long history. By the Early Iron Age, the eastern part of the Kashkadarya oasis - the ancient Kitab - Shakhrisabz, Yakkabag - began to be rapidly developed.

Early agricultural areas appeared in the Kesh oasis, and after many years of research, it can be concluded that the Kesh oasis was not excluded from the socio-economic, cultural and political processes that took place in the ancient East.

\footnotetext{
${ }^{11}$ Views from the history of ancient KeshShakhrisabz // Editor-in-Chief: A.S. Sagdullaev.T. "Shark" 1998.
} 
V.V.Bartold,

V.L.Viyatkin,

B.Denike, A.Yu.Yakubovsky, B.N.Zasipkin, Ya.G.Gulomov, T.M.Mirgiyosov, S.K.Kabanov, S.A.Sudakov, in the detailed coverage of the ancient and medieval history of the Kesh oasis. The research of such researchers as V.L.Varonina, G.N.Gachanov, M.E.Masson, G.A.Pugachenkova, O.A.Sukhareva is of great importance.

Similar expeditions were carried out in the following periods. Among them are R.H. Suleymanov and A.S. Sagdulliev. Archaeological research of these scientists served as an important basis in determining the age of the cities of the eastern (Kesh) and western (Karshi) oases of Kashkadarya and their place in the urban culture of Central Asia.

In conclusion, the above views also prove that the Kesh oasis is probably one of the most developed oases in eastern Sogdia and Central Asia, and it has close cultural ties with neighboring regions. Therefore, there is a growing interest in the study of this oasis, which is one of the most important tasks facing archaeologists.

\section{REFERENCES}

1. Views from the history of ancient KeshShakhrisabz // Editor-in-Chief: A.S.Sagdullaev.T. "Shark" 1998.

2. Askarov A. Eng qadimiy shaxar. - T. 2001 yil.

3. Ravshanov P. History of Karshi. T., New Generation, 2006.

4. Rtveladze E.V. Buryakov. Yu.F, Sulaymonov. R.X. Karshi T. Manaviyat, 2006.

5. Rtveladze.E.V Etyud po istoricheskoy geografii Baktrii i Sogdiany vo vremya pokhoda Aleksandra Makedonskogo / VDI 2000.
6. Rtveladze.E.V, Saidov A.H, Abdullaev E.V, Civilization of ancient Uzbekistan: Views from the history of statehood and law. T., 2001.

7. Sagdullaev A.S. Ancient Uzbekistan in the first written sources.T., 1996.

8. Staviskiy. B. Or Sudby Buddhism in Central Asia. M., 1998.

9. Hasanov. M., and Mexendali.S. Raskopki na Sangirtepe v Kashkadary // Arxeologicheskie isseledovaniya $\mathrm{V}$ Uzbekistana. 2003 T "Uzbek National Encyclopedia" 2004. 